\title{
ANALYSIS OF CORNEAL ASTIGMATISM AFTER CLEAR CORNEAL PHACOEMULSIFICATION : A PROSPECTIVE STUDY
}

\author{
Agrawal $N^{1^{*}}$, Agarwal $L^{2}$, Yadav $R^{3}$, Kumari $A^{4}$, Singh $K^{5}$, Baral $D^{6}$
}

\section{Affiliation}

1. Consultant, Cataract and Phaco Specialist, Taparia Eye Care Pvt. Ltd., Nepal

2. Assistant Prof NAMS, Head, Department of Vitreo-retina, Biratnagar Eye Hospital

3. Department of Cornea and External Diseases, Sagarmatha Chaudhary Eye Hospital

4. Vitreo-retina consultant, Prasad Eye Hospital, Ramgarh

5. Consultant Cataract and Phaco Surgeon, Vasan Eye Care

6. Associate Professor, School of Public Health and Community Medicine, BP Koirala Institue of Health Sciences

\section{ARTICLE INFO}

Received : 28 August, 2019
Accepted : 27 August, 2020
Published : 05 October, 2020

(C) Authors retain copyright and grant the journal right of first publication with the work simultaneously licensed under Creative Commons Attribution License CC - BY 4.0 that allows others to share the work with an acknowledgment of the work's authorship and initial publication in this journal.

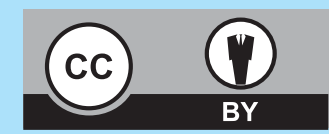

ORA 171

DOI: : https://doi.org/10.3126/bjhs.v5i2.31371

\author{
* Corresponding Author \\ Dr. Nisha Agrawal \\ Consultant, Catract and Phaco Specialist \\ Taparia Eye Care Pvt. Ltd., Nepal \\ Email ID: doctor.nisha.agrawal@gmail.com \\ ORCID ID: https://orcid.org/0000-0001-7626-9506
}

\section{Citation}

Agrawal N, Agarwal L, Yadav R, Kumari A, Singh K, Baral D. Analysis of Corneal Astigmatism after Clear Corneal Phacoemulsification: A Prospective Study. BJHS 2020;5(2)12: 1001-1005.

\section{ABSTRACT}

\section{Introduction}

With the evolution of cataract surgery over the past years and increasing patient demand for spectacle independence, today cataract surgery is moreover a refractive surgery. Surgically induced astigmatism (SIA) hinders post-operative refractive precision by changing the refractive power of cornea.

\section{Objectives}

To calculate and compare SIA and postoperative spherical equivalent (SE) among eyes undergoing phacoemulsification performed via superior and temporal approach.

\section{Methodology}

A longitudinal prospective observational study was conducted in a tertiary eye care center. 200 consecutive patients who underwent $2.8 \mathrm{~mm}$ clear corneal phacoemulsification were allocated in Group A (Superior) and Group B (Temporal) in equal numbers by random lottery method. Patients with any corneal pathology, glaucoma, retina or macular diseases, with previous history of trauma or ocular surgery were excluded. Preoperative astigmatism, postoperative astigmatism and postoperative SE were calculated at 6 weeks follow-up. SIA was calculated using vector analysis software version 2.1 given by Dr Sawhney.

\section{Results}

Eighty patients of group A and 99 patients of Group B were included in the analysis. Preoperative keratometry and astigmatism was comparable between the two groups. Postoperative astigmatism was significantly lower in temporal incision $(0.75 \pm 0.58)$ group than in superior incision group (1.2 \pm 0.71$)$. SIA in-group A was $0.43 \mathrm{D}$ and in group B was $0.18 \mathrm{D}$. SE was found to be significantly lower in temporal incision $(p<0.01)$ group.

\section{Conclusion}

Temporal incision is astigmatically more neutral and has better refractive precision than superior incision clear corneal phacoemulsification.

\section{KEYWORD}

Astigmatism, cataract surgery, phacoemulsification, surgically induced astigmatism, spherical equivalent 


\section{INTRODUCTION}

Cataract surgery is one of the long practiced ophthalmic surgical procedures. It has evolved tremendously from the era of couching to intracapsular cataract extraction, small incision cataract surgery and the latest technique being phacoemulsification. In this technique ultrasound probe emulsifies cataractous lens intraocularly through an incision as small as $3 \mathrm{~mm}$ (or lesser). These advancements in surgical technique and the use of toric or multi focal IOL have raised cataract surgery to refractive surgery platform. At the same time patients' expectations have increased for fast visual recovery and spectacle independence.

Cornea being a refractive surface, the moment a keratome passes through the cornea, it changes its surface curvature and power. Incision length, location, architecture and wound suturing inculcates surgically induced astigmatism (SIA). ${ }^{1}$ SIA affects visual outcome and is still a hurdle in acquiring spectacle independence. This study was thus carried out to calculate SIA, postoperative spherical equivalent and to compare them amongst superior and temporal clear corneal incision. In this study, measures to reduce SIA have been discussed, which can help surgeons to improve surgical outcome.

\section{METHODOLOGY}

A longitudinal prospective observational study was carried out at cataract department of Biratnagar Eye Hospital. Two hundred patients who underwent phacoemulsification in immature cataract were enrolled in the study. Institution review board approved this study and written informed consent was obtained from all the study participants.

The patients were assigned into two groups (100 in superior incision group and 100 in temporal incision group) by random lottery method. Patients with corneal opacity and other corneal pathologies, glaucoma, retina or macular diseases, previous history of trauma or ocular surgery were excluded. All the cases were operated by a single surgeon (NA) under peribulbar block. $0.5 \mathrm{ml}$ of bupivacaive mixed with adrenalin was administered with 26Ga needle. They underwent phacoemulsification (CataRhex easy, VC820100CE, Oertli) through a $2.8 \mathrm{~mm}$ clear corneal incision made superiorly (Group A) or temporally (Group B). Two side port incisions were made $90^{\circ}$ away from the main incision. This was followed by implantation of a single piece foldable IOL with injector-cartridge system. IOL power calculation was done by SRK T formula. All the incisions were closed by stromal hydration and left sutureless. Postoperative regimen consisted of steroid antibiotic combination (ciprofloxacin and dexamethasone) used 6 times a day for the first week and gradually tapered over 6weeks.

Patient's demographic details, slit lamp examination findings, operated eye (whether right or left eye), preoperative visual acuity were recorded. Preoperative vertical and horizontal keratometry (corneal curvature: KV and $\mathrm{KH}$ respectively), 6 weeks postoperative $\mathrm{KV}, \mathrm{KH}$ were recorded in $\mathrm{mm}$ by autorefractometer (Nidek US-500 ECHOSCAN). The millimeter keratometer readings were converted to Diopteric value with the help of conversion table. IOL power calculation was done by non-contact method (IOL master) and cross checked with manual keratometry method. Refractive error was ascertained using manual retinoscopy.

Statistical analysis: Collected data were entered in the Micro-Soft EXCEL sheet and converted into SPSS 11.5 Version for statistical analysis. For descriptive statistics percentage, the mean and standard deviation were calculated for categorical and numerical data respectively. For inferential statistics, a comparison was done between surgically induced astigmatism and refractive error of the two groups and other selected variables at $95 \% \mathrm{Cl}$ where the level of significance was considered at $p<0.05$. Surgically induced astigmatism and refractive error of the two groups were compared.

\section{RESULTS}

Of the total 100 patients in each group, 80 patients from group $A$ and 99 patients from group B completed the followup protocol and were included in the analysis. Mean age of the patients in group $A$ was $57.62 \pm 10.502$ years and in group $B$ was $56.46 \pm 11.381$ years $(p=0.484)$. Equal numbers of men (M) and women (F) were there in Group A (Figure 1). Gender distribution ratio was non-significantly different (M: $\mathrm{F}=60: 39$ ) among patients of Group B (Figure 1). Majority of patient's Right eye (Group $A=58.7 \%$, Group $B=57.5 \%$ ) was operated in both the groups (Figure 2). The two groups were comparable in terms of non-significant differences in preoperative vision, horizontal keratometry $(\mathrm{KH})$, vertical keratometry (KV) and preoperative astigmatism(Table1). Post-operative astigmatism was significantly lower $(p<0.001)$ in temporal incision group $(0.7453 \mathrm{D})$ than in superior incision group (1.2D) (Table 1 ).

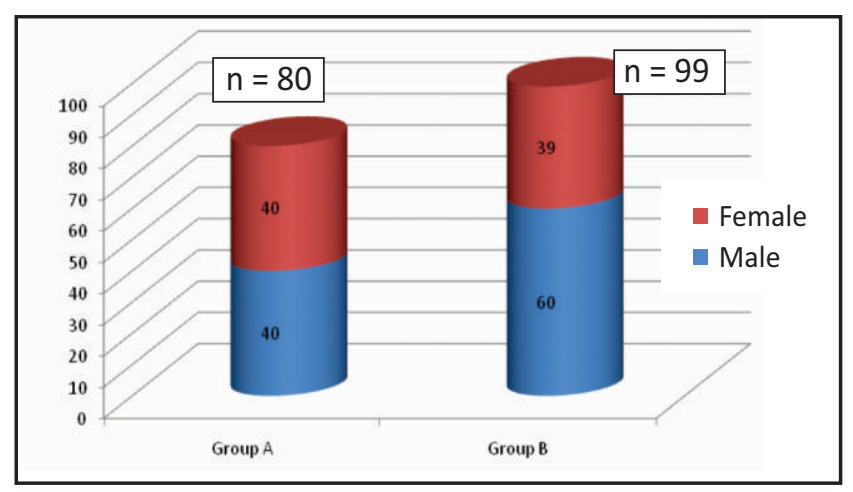

Figure 1: Gender distribution details in between the two groups 


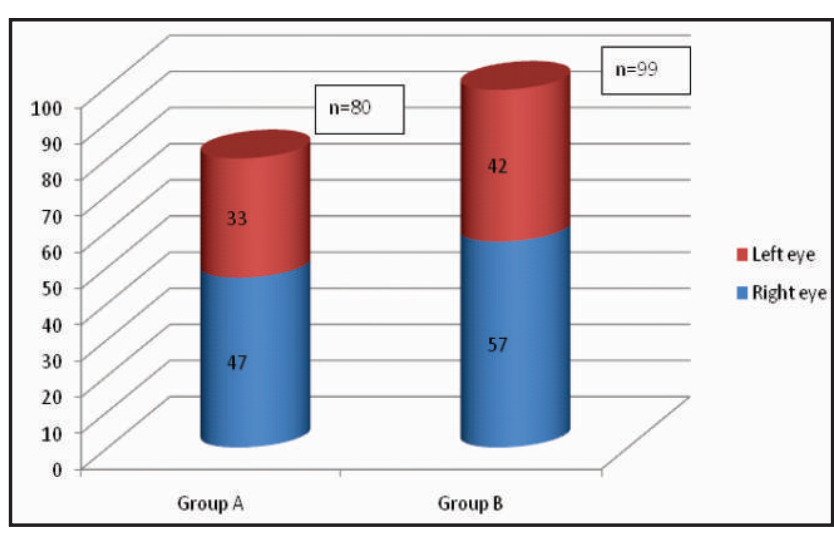

Figure 2: Operated eye distribution details in between the two groups.

\begin{tabular}{|c|c|c|c|c|c|}
\hline Variables & Incision & $\mathbf{N}$ & Mean & $\begin{array}{l}\text { Standard } \\
\text { Deviation }\end{array}$ & $\begin{array}{c}\text { Sig. } \\
\text { (2-tailed) }\end{array}$ \\
\hline \multirow{2}{*}{$\begin{array}{l}\text { Preoperative visual } \\
\text { acuity (logMAR) }\end{array}$} & Group A & 80 & 1.0783 & 0.33762 & \multirow{2}{*}{0.332} \\
\hline & Group B & 99 & 1.1354 & 0.42788 & \\
\hline \multirow{2}{*}{$\begin{array}{l}\text { Preoperative } \\
\text { Keratometry } \\
\text { Horizontal (D) }\end{array}$} & Group A & 80 & 43.9729 & 1.72459 & \multirow{2}{*}{0.568} \\
\hline & Group B & 99 & 44.2237 & 3.60344 & \\
\hline \multirow{2}{*}{$\begin{array}{l}\text { Preoperative Axis } 1 \\
\text { (Degree) }\end{array}$} & Group A & 80 & 90.88 & 77.873 & \multirow{2}{*}{0.541} \\
\hline & Group B & 99 & 84 & 71.945 & \\
\hline \multirow{2}{*}{$\begin{array}{l}\text { Preoperative } \\
\text { Keratometry } \\
\text { Vertical (D) }\end{array}$} & Group A & 80 & 43.4951 & 1.79366 & \multirow{2}{*}{0.363} \\
\hline & Group B & 99 & 43.2619 & 1.62502 & \\
\hline \multirow{2}{*}{$\begin{array}{l}\text { Preoperative Axis } 2 \\
\text { (Degree) }\end{array}$} & Group A & 80 & 91.01 & 18.797 & \multirow{2}{*}{0.474} \\
\hline & Group B & 99 & 93.52 & 26.258 & \\
\hline \multirow{2}{*}{$\begin{array}{l}\text { Preoperative } \\
\text { astigmatism (D) }\end{array}$} & Group A & 80 & 0.7895 & 0.53097 & \multirow[t]{2}{*}{0.969} \\
\hline & Group B & 99 & 0.7926 & 0.52312 & \\
\hline \multirow{2}{*}{$\begin{array}{l}\text { Postoperative } \\
\text { astigmatism (D) }\end{array}$} & Group A & 80 & 1.2 & 0.71023 & \multirow{2}{*}{$<0.01$} \\
\hline & Group B & 99 & 0.7453 & 0.57549 & \\
\hline \multirow{2}{*}{\begin{tabular}{|l|} 
Postoperative \\
spherical equivalent
\end{tabular}} & Group A & 80 & 0.27181 & 0.461313 & \multirow{2}{*}{$<0.01$} \\
\hline & Group B & 99 & 0.06061 & 0.252768 & \\
\hline
\end{tabular}

With superior incision, there was flattening of vertical keratometry $(p<0.01)$ and steepening of horizontal keratometry $(p=0.192)$. In case of temporal incision group, there was non-significant flattening of both the vertical and horizontal meridians. Following surgery, visual acuity significantly improved in both the groups. There was significant increase in postoperative astigmatism in the superior incision group $(p<0.01)$. Whereas there was non-significant decrease in astigmatism in the temporal incision group $(p=0.424)$ (Table 2). Surgicallly induced astigmatism as calculated by vector analysis was found to be lower in temporal incision group (Table 3).Emmetropia was achieved in $25 \%$ cases of group $A$ and $27.27 \%$ cases of group B (Table 4). Postoperative spherical equivalent was significantly lower in group $B$ than in group A (Table 1) concluding that temporal incision was temporally more neutral with lesser residual astigmatism and more propensities to achieve emmetropia.
Table 2: Comparison of Preoperative and postoperative parameters ( 6 weeks post-surgery) in superior and inferior incision group.

\begin{tabular}{|l|l|r|r|c|}
\hline & & Preoperative & Postoperative & p value \\
\hline \multirow{2}{*}{$\begin{array}{l}\text { Keratometry } \\
\text { Horizontal }\end{array}$} & Group A & 43.9729 & 44.0706 & 0.192 \\
\cline { 2 - 5 } $\begin{array}{l}\text { Keratometry } \\
\text { Vertical }\end{array}$ & Group B & 44.2237 & 43.5975 & 0.073 \\
\cline { 2 - 5 } $\begin{array}{l}\text { Best corrected } \\
\text { Visual Acuity }\end{array}$ & Group B & 43.4951 & 43.168 & $<0.01$ \\
\cline { 2 - 5 } & Group A & 43.2619 & 43.208 & 0.376 \\
\hline Astigmatism & Group B & 1.0783 & 0.3493 & $<0.01$ \\
\cline { 2 - 5 } & Group B & 0.1354 & 0.2941 & $<0.01$ \\
\hline
\end{tabular}

Table 3: Details of Surgically Induced Astigmatism in the two groups

\begin{tabular}{|l|c|c|c|}
\hline & SIA & Axis & Coherence \\
\hline Group A & 0.43 D & 6 degree & $51 \%$ \\
\hline Group B & 0.18 D & 109 degree & $22 \%$ \\
\hline
\end{tabular}

Table 4: Details of postoperative spherical equivalent of the Superior and inferior incision groups

\begin{tabular}{|l|l|l|l|}
\hline $\begin{array}{l}\text { Spherical equivalent } \\
\text { category }\end{array}$ & Group A & Group B & p value \\
\hline 0 & $20(25 \%)$ & $27(27.27 \%)$ & \multirow{2}{*}{0.153} \\
\cline { 1 - 3 } Myopic shift & $47(58.75 \%)$ & $65(65.66 \%)$ & \\
\hline Hypermetropic shift & $13(16.25 \%)$ & $07(07.07 \%)$ & \\
\hline
\end{tabular}

\section{DISCUSSION}

In the present era, due to increasing desire of spectacle independence, cataract surgery has become moreover a refractive surgery requiring high refractive precision. Postoperative astigmatism is governed by two factors: pre-operative astigmatism and surgically induced astigmatism (SIA). ${ }^{2,3}$ Pre-operative astigmatism is a non-modifiable factor whereas SIA is a modifiable factor. SIA is in return influenced by many surgeon related factors like incision length, location, site, architecture and use of sutures which have varied role to play in determining SIA. ${ }^{4}$ High SIA with high residual refractive error could lead to dissatisfaction among surgeons and unhappy patients.

\section{Location of incision}

Surgically induced astigmatism is also affected by location of incision. ${ }^{4}$ The farther the incision is from the centre of visual axis the lesser is the astigmatism. Scleral incisions induce least astigmatism followed by limbal incision, maximum SIA being induced by clear corneal incision. In a study by Kagnici and colleagues comparing superior limbal incision with superior clear corneal incision, lesser astigmatism was found in limbal group. ${ }^{5}$ However, this finding could not attain statistical significance in their study. Inspite of having higher astigmatic effect and delayed wound healing as a result of its avascularity, clear corneal incisions are widely practiced. This is because they have advantage of sparing the conjunctiva from scarring which can be reserved for future possible glaucoma surgery. ${ }^{6}$

\section{Size of incision}

The size of incision has a great role to play in terms of SIA. 
Smaller incisions have least astigmatism as compared to large incisions. They have added advantage of better intra operative chamber stability and faster wound healing. ${ }^{7}$ Many authors have studied the effect of size of incision over astigmatism in the past. Masket and his friends compared $2.2 \mathrm{~mm}$ coxial phacoemulsification with $3 \mathrm{~mm}$ incision. They found that $2.2 \mathrm{~mm}$ group had significantly low SIA. ${ }^{8}$ Some authors also debate on the fact that too small incisions cause irreversible stretching of wound leading to compromise of wound architecture. Moon SC et al supported this finding in their study comparing SIA in incision sizes of $2.5 \mathrm{~mm}, 3 \mathrm{~mm}$ and $3.5 \mathrm{~mm}{ }^{4}$ They concluded that $3.0 \mathrm{~mm}$ incision was astigmatically most stable in comparison to that on $2.5 \mathrm{~mm}$ and $3.5 \mathrm{~mm}{ }^{4}$

\section{Site of incision}

Incision on cornea causes flattening of that meridian due to wound gaping, tissue addition at that site and increase in radius of curvature. ${ }^{9}$ Similar flattening of vertical meridian in superior incision group and horizontal meridian in temporal incision group was found in our study. In a study by Susic they observed flattening of vertical meridian and not much change in horizontal meridian. ${ }^{1}$

In this study, clear corneal superior incision was found to have significantly higher postoperative astigmatism in comparison to preoperative astigmatism $(p<0.01)$. The temporal group had less astigmatism postoperatively but this finding couldn't attain statistical significance $(p=0.424)$. SIA was found to be higher in superior group than that of temporal group. Yaycıoğlu and his colleagues found that astigmatism was maximum with nasal incision followed by superior, superior-temporal and least with temporal incision. ${ }^{10}$ With nasal incision maximum stress was induced over the incision because of perpendicular entrance of phaco probe. ${ }^{11}$ Superior incisions induce greater astigmatism due to its proximity to visual centre of the cornea and variable pressure effect on wound architecture by the eyelid. ${ }^{5}$ Many study findings match our results concluding that SIA was maximum with superior incision than with temporal incision. ${ }^{12-14}$ Susic and his friends studied the effect of oblique incision on astigmatism. No significant difference was noted by them while comparing superonasal incision in right eye with supero-temporal incision in left eye. ${ }^{1}$ Temporal incision was compared with incision on steep axis by Borasio et al and they concluded that temporal incision group was associated with lesser SIA. ${ }^{15}$

In the present study, post-operative visual acuity improved significantly in all the patients of both groups. Mean $( \pm S D)$

\section{REFERENCES}

1. SušićN,Brajković J, Kalauz-Surać I. Analysis of Postoperative Corneal Astigmatism after Phacoemulsification Through a Clear Corneal Incisions. ActaClin Croat 2007;46(1):37-40.

2. Albert D.M., Miller J.W., AzarD.T,Blodi B.A. (2008) Principles and Practice of Ophthalmology. 3rd Edition, Saunders Company, Philadelphia, Chapter 120 spherical equivalent in group $A$ was found to be $0.27 \pm 0.46 \mathrm{D}$ which was significantly higher than that of group $B(0.06 \pm 0.25 D)$. This implies that there was lesser residual refractive error in temporal incision group than in superior incision group.

Studies have also compared inter-surgeon changes in postoperative astigmatism. A study compared the SIA of four surgeons who operated with same location, site, size and architecture of incision. It was found that there was no significant difference in astigmatism amongst the four surgeons concluding that SIA was more dependent on incision related factors than surgeon related factors. ${ }^{16}$

Scholars have suggested that those who invariably operate on temporal axis will have variable results. Surgeons should move around the eye in accessible field to operate on the steep axis to get better postoperative refractive outcome. If preoperative against the rule astigmatism is $<1 D$ then it is better to operate on temporal (horizontal) meridian.

\section{CONCLUSION}

Temporal incisions in phacoemulsification are astigmatically more neutral than superior incisions. They also have lesser postoperative residual refractive error, which have higher propensity of spectacle independence.

\section{RECOMMENDATIONS}

It is recommended that cataract surgeons should operate temporally for lesser surgically induced astigmatism and residual postoperative refractive error.

\section{LIMITATION OF STUDY}

1. Only temporal and superior incisions were considered. Oblique and nasal incisions were not studied.

2. All the incisions were of $2.8 \mathrm{~mm}$ and other incision sizes were not taken into consideration.

3. All the incisions were clear corneal and other incision locations were not taken into consideration.

4. Single surgeon operated all the cases and inter surgeon variability was not analysed.

\section{ACKNOWLEDGEMENT}

None

\section{CONFLICT OFINTEREST}

None

\section{FINANCIAL DISCLOSURE}

None

3. Henderson B., Pineda R., Ament C., Chen S, Kim, J. (2007) Essentials of Cataract Surgery. Slack Incorporated, Online Library, Chapter 7.

4. Moon SC, Mohamed T, Fine IH. Comparison of Surgically Induced Astigmatisms after Clear Corneal Incisions of Different Sizes. Korean Journal of Ophthalmology 2007; 21(1):1-5 .DOI: 10.3341/ kjo.2007. 21.1.1. 
5. Kağnici, DB, Kocatürk, T, Çakmak, H, Dündar, SO. Surgically Induced Corneal Astigmatism Following Cataract Surgery. Open Journal of Ophthalmology 2015; 5: 47-53. DOI:10.4236/ojoph.2015.52008

6. Barequet IS, Yu E, Vitale S, Cassard S, Azar DT, Stark WJ. Astigmatism Outcomes of Horizontal Temporal versus Nasal Clear Corneal Incision Cataract Surgery. Journal of Cataract Refractive Surgery 2004; 30(2): 418-423.DOI:10.1016/S0886-3350(03)00492-9

7. Phleger T, Scholz U, Skorpik C. Postoperative astigmatism after nostitch, small incision cataract surgery with $3.5 \mathrm{~mm}$ and $4.5 \mathrm{~mm}$ incision. J Cataract Refract Surg1994;20:400-5. PMID:7932128 DOI:10.1016/s0886-3350(13)80174-5.

8. Masket E, Wang L, Belani S. Induced astigmatism with 2.2- and 3.0$\mathrm{mm}$ coaxial phacoemulsification incisions. J Refract Surg. 2009;25(1):21-4. PMID:19244949.

9. Freitas GO, Boteon JE, Carvalho MJ, Pinto RMC. Astigmatism treatment during phacoemulsification: a review of current surgical strategies and their rationale. Rev Bras Ophtalmol 2013; 72 (6): 41923. DOI:10.1590/S0034-72802013000600013

10. Yaycioglu, A., Akova, Y.A., Akca, S., Gur, S. and Oktem, C. Effect on Astigmatism of the Location of Clear Corneal Incision in Phacoemulsification of Cataract. Journal of Refractive Surgery 2007; 23: 515-518. PMID:17523515
11. Kohnen, S, Neuber R, Kohnen, T. Effect of Temporal and Nasal UnsuturedLimbal Tunnel Incisions on Induced Astigmatism after Phacoemusification. Journal of Cataract Refractive Surgery 2002; 28: 821-825. DOI: 10.1016/S0886-3350(01)01215-9.

12. TejedorJ,Pérez-Rodríguez JA. Astigmatic Change Induced by $2.8 \mathrm{~mm}$ Corneal Incisions for Cataract Surgery. Investigative Ophthalmology \& Visual Science March 2009; 50: 989-994. DOI:10.1167/iovs.082778.

13. Nikose AS, Saha D, Laddha PM, Patil M. Surgically induced astigmatism after phacoemulsification by temporal clear corneal and superior clear corneal approach: a comparison. ClinOphthalmol2018 Jan 3;12:65-70. DOI:10.2147/OPTH.S149709.

14. MerriamJC,Zheng L, Cheng B. Effect of Incision Size and Location on Surgically-Induced Astigmatism (SIA). Investigative Ophthalmology \& Visual Science 2009,50(13), 55-67. PMID-2367933

15. Borasio E, Mehta JS, Maurino V. Surgically induced astigmatism after phacoemulsification in eyes with mild to moderate corneal astigmatism: temporal versus on-axis clear corneal incisions. J Cataract Refract Surg. 2006 Apr;32(4):565-72. PMID: 16698473. DOI:10.1016/j.jcrs.2005.12.104

16. Theodoulidou S, Asproudis I, Athanasiadis A, Kokkinos M, Aspiotis M. Comparison of surgically induced astigmatism among different surgeons performing the same incision. Int J Ophthalmol. 2017; 10(6): 1004-1007. DOI: 10.18240/ijo.2017.06.26 